\title{
Prevalence of Risk Factors for Chronic Kidney Disease in a Coastal Area of Tamil Nadu, South India.
}

\author{
Venkatachalam.J ${ }^{1}$, Murugan $\mathrm{N}^{2}$, Abraham $\mathrm{SB}^{3}$, Zile Singh ${ }^{4}$, Dr. Anil J, Purty ${ }^{5}$ \\ Sathya GR ${ }^{6}$ \\ ${ }^{1,2}$ Assistant Professor, Department of Community Medicine, Pondicherry Institute of Medical Sciences \\ ${ }^{3}$ Post Graduate student, Department of Community Medicine, Pondicherry Institute of Medical Sciences \\ ${ }^{4}$ Professor and HOD, Department of Community Medicine, Pondicherry Institute of Medical Sciences \\ ${ }^{5}$ Professor, Department of Community Medicine, Pondicherry Institute of Medical Sciences \\ ${ }^{6}$ Post Graduate student, Department of Physiology, Pondicherry Institute of Medical Sciences
}

\begin{abstract}
Communicable Diseases which were the leading causs of mortality in the beginning of the twentieth century have now been replaced by Non-Communicable Diseases which account for almost two-thirds of all deaths presently in India. Considering the high prevalence of CKD risk factors it has long been presumed that CKD represents a major public health problem in our country. This study was conducted to determine the risk factors of CKD.

Materials and Methods: A community based cross sectional study was conducted among the 1200 respondents, 20 years and above, residing in a coastal area of Villupuram district, over a period of 6 months (Feb-July) using a pre-structured and validated questionnaire. The questionnaire included information on demographic characteristics, lifestyle habits, and awareness of CKD risk factors. Random blood sugar and spot urinary protein and sugar using urinalysis dipsticks were measured. Data was analyzed using SPSS 16.0 version, $p$ value $<0.05$ was considered significant.

Results: Majority of the respondents were females (67.8\%) with maximum belonging to the age group of 20$29 y$ rs (23.8\%), followed by 30-39yrs (22.8\%).Most of them belonged to upper lower class (31.8\%), followed by lower middle class (25.8\%). $93.1 \%$ of the population were Muslims with $87.9 \%$ belonging to backward caste. The prevalence of CKD risk factors among the respondents were Proteinuria(12.5\%), Glycosuria(8.4\%), Hypertension (24.3\%), Diabetes Mellitus(18\%) and Obesity (44.4\%).

Conclusion: Prevalence of CKD risk factors in the study area was moderate to high. Hence, policies and programmes should focus on these areas and IEC should focus on creating awareness about CKD risk factors in the community.
\end{abstract}

Key words: Prevalence, non-communicable diseases, CKD, risk factors.

\section{Introduction}

Communicable Diseases which were the leading causes of mortality in the beginning of the twentieth century have now been replaced by cardiovascular diseases, stroke, diabetes, cancer and accidents which account for almost two-thirds of all deaths presently in India ${ }^{[1]}$. One such situation being faced now by India and several others is the increasing prevalence of Chronic Kidney Disease. According to National Kidney Foundation (NKF) guidelines, CKD is defined as either kidney damage or Glomerular Filtration Rate (GFR) below $60 \mathrm{ml} / \mathrm{min} / 1.73 \mathrm{~m}^{2}$ for three or more months with or without evidence of kidney damage, irrespective of the cause ${ }^{[2]}$. Evidence suggests that hypertension and diabetes are the two major causes of kidney disease worldwide ${ }^{[3,4]}$. According to the International Diabetes Federation, India stands second only to China with respect to world diabetes with 61.3 million in 2011 and the CURES cohort suggested that every fifth person in India is hypertensive ${ }^{[5]}$.In 2003, the American Heart Association (AHA) stated that persons with CKD should be regarded as the highest risk group for subsequent $\mathrm{CVD}^{[6]}$.

Patients with CKD are at high risk for progression to end stage renal disease (ESRD). Progress to kidney failure or other adverse outcomes could be prevented or delayed by early detection and treatment with population based screening ${ }^{[7,8]}$.

Considering the high prevalence of CKD risk factors it has long been presumed that CKD represents a major public health problem in our country, at least in urban India. In our study, we aim to ascertain the risk factors for CKD prevalence in the community; screening study subjects based on standard clinical features of $\mathrm{CKD}$ in a resource limited setting. 


\section{Materials and Methods}

A cross sectional study was carried out in a coastal area of Villupuram district of Tamilnadu. Study Period: Six months (February-July 2012). Study Tool: Pre-designed structured questionnaire - interviewed by final year part 1 MBBS students, Interns and Post graduates, Department of Community Medicine. Study Variables Socio-demographic factors, CKD risk factors, Life style factors, Anthropometry, Clinical examination, Random blood sugar, Indian urine dipstick analysis for urinary sugar and protein. Association between variables was studied. Data was analyzed using SPSS 16.0 version. Sample size: Estimated sample size calculated for survey was 1111. (Considering prevalence of Hypertension $-20 \%$ and precision-12\%). We studied 1200 individuals keeping in view attrition of study subjects. Inclusion and exclusion criteria: All adults in the age group of 18 years or more, both male and female, who were willing, were included in the study. The individuals below the age of 18 and those who were not willing for the study or those not available for interview on account of their absence on more than three visits were excluded. Sampling method: The study was carried out during February-March in 2012. Initially a pilot study was carried out, preliminary analysis was done to reformate the questionnaire, and the proforma was finalized. House to house visit was carried out in the defined area using predefined and pre-tested proforma. Proper history and examination of all the participants were carried out. All persons of more than 18 years of age in the visited house were covered in the survey. After the completion of interview, people were educated about the importance of adopting a healthy life style and other health education was also given in relation to Chronic Kidney Disease. Body mass index (BMI) was calculated by dividing weight in $\mathrm{kg}$ by square of height in meters. Overweight/ obesity were estimated based on BMI $>23.0 \mathrm{~kg} / \mathrm{m}^{2}$. Hypertension was defined based on a systolic blood pressure $>140 \mathrm{~mm}$ of $\mathrm{Hg}$ or diastolic blood pressure $>90 \mathrm{~mm}$ of $\mathrm{Hg}$. Diabetes was defined as fasting blood glucose $>7.0 \mathrm{mmol} / \mathrm{L}(126 \mathrm{mg} / \mathrm{dl})$ and random blood glucose more than $200 \mathrm{mg} / \mathrm{dl}$ or a previous diagnosis of diabetes mellitus as per the American Diabetes Association (ADA) criteria 2003-4. ${ }^{[9]}$ Standard definitions were used to measure physical activity, hypertension ${ }^{[6]}$ obesity and central obesity ${ }^{[7]}$. Statistical analysis: The statistical software SPSS version 16 was used for data analysis. Using chi square and odds ratio, association between variables were studied

\section{Results}

Table 1 shows: Majority of the respondents were females (67.8\%), maximum number belonging to the age group of 20-29yrs (24\%), followed by 30-39yrs (22.7\%). Most of them belonged to upper lower class (31.8\%), followed by lower middle class (25.8\%). $93.1 \%$ of the population were Muslims and only 5.9\% Hindus, with $87.9 \%$ belonging to BC. Most of the population resided in pucca houses $(88 \%)$ and only $3.1 \%$ of the population resided in kutcha houses. The prevalence of protenuria were high among males and elderly people which found to be statistically significant.

Table1: Sociodemographic Characteristics of the Study Population

\begin{tabular}{|c|c|c|c|c|}
\hline Characteristic & $\begin{array}{c}\text { Frequency } \\
\mathrm{N}=1200\end{array}$ & Percentage (\%) & $\begin{array}{c}\text { Proteinuria } \\
\mathrm{N}(\%) \\
\mathrm{N}=148\end{array}$ & $p$ value \\
\hline \multicolumn{5}{|l|}{ Gender } \\
\hline Male & 387 & 32.2 & $66(17.1)$ & \multirow[t]{2}{*}{0.01} \\
\hline Female & 813 & 67.8 & 82(10.1) & \\
\hline \multicolumn{5}{|l|}{ Age } \\
\hline $20-29$ & 288 & 24.0 & $18(6.2)$ & \multirow[t]{6}{*}{0.001} \\
\hline $30-39$ & 273 & 22.7 & $22(8.1)$ & \\
\hline $40-49$ & 223 & 18.6 & $27(12.1)$ & \\
\hline $50-59$ & 229 & 19.1 & 44(19.2) & \\
\hline$>60$ & 187 & 15.6 & 37(19.8) & \\
\hline Mean Age: & 50.28 & SD:15 & 95\% CI : (47.72-52.84) & \\
\hline \multicolumn{5}{|c|}{ Socioeconomic status } \\
\hline Upper & 103 & 8.6 & $12(11.7)$ & \multirow[t]{5}{*}{0.06} \\
\hline Upper middle & 257 & 21.4 & $43(16.7)$ & \\
\hline Lower middle & 309 & 25.8 & 42(13.6) & \\
\hline Upper lower & 382 & 31.8 & $35(9.2)$ & \\
\hline Lower lower & 149 & 12.4 & $16(10.7)$ & \\
\hline \multicolumn{5}{|l|}{ Religion } \\
\hline Hindu & 71 & 5.9 & $6(8.5)$ & \multirow[t]{3}{*}{0.243} \\
\hline Muslim & 1117 & 93.1 & 142(12.7) & \\
\hline Christian & 12 & 1.0 & $\mathbf{0}(\mathbf{0})$ & \\
\hline \multicolumn{5}{|l|}{ Caste } \\
\hline $\mathrm{SC} / \mathrm{ST}$ & 24 & 2.0 & $3(12.5)$ & \multirow[t]{3}{*}{0.569} \\
\hline BC & 1056 & 88 & $128(12.1)$ & \\
\hline General & 120 & 10 & $17(14.7)$ & \\
\hline
\end{tabular}




\begin{tabular}{|ccccc|}
\hline Housing condition & & & & \\
Kutcha & 36 & 3.0 & $\mathbf{6}(16.7)$ & 0.544 \\
Pucca & 1056 & 88 & $10(9.1)$ & \\
Semi pucca & 108 & 9 & $132(12.5)$ & \\
\hline
\end{tabular}

CKD risk factors versus socioeconomic status

Prevalence of diabetes mellitus based on socio economic status showed that the people belonging to upper class $21(20.4 \%)$ had more prevalence of diabetes compared to lower socioeconomic respondent 71(13.4\%). Similarly, hypertension prevalence was also high among upper class $25(24.3 \%)$ compared to lower class $88(16.6 \%)$. Overweight/obesity was higher $31(30 \%)$ in upper class than lower class $106(20 \%)$. High salt intake: was high among lower class $436(82.1 \%)$ compared to upper class $81(78.6 \%)$. The prevalence of alcohol consumption was high in upper class respondent 3(2.9\%) compared to middle class 12(2.1\%). Smoking was high in middle class compared to upper class. Renal calculus was high in lower class $32(6 \%)$. The prevalence of UTI was high in middle $30(5.3 \%)$ and lower class $24(4.5 \%)$ compared to upper class were none of them had UTI.(table-2)

Table2: CKD's Risk Factors Prevalence in Association with Socio-Economic Status

\begin{tabular}{|c|c|c|c|c|c|}
\hline CKDs risk factors & $\begin{array}{l}\text { Upper } \\
\text { No(\%) } \\
\mathbf{N}=103\end{array}$ & $\begin{array}{l}\text { Middle } \\
\text { No(\%) } \\
\text { N=566 }\end{array}$ & $\begin{array}{l}\text { Lower } \\
\text { No(\%) } \\
\text { N=531 }\end{array}$ & $\begin{array}{l}\text { Total } \\
\text { No(\%) } \\
\text { N=1200 }\end{array}$ & p value \\
\hline \multicolumn{6}{|l|}{ Diabetes } \\
\hline Yes & $\begin{array}{l}21(20.4) \\
82(79.6)\end{array}$ & $\begin{array}{l}92(16.3) \\
474(83.7)\end{array}$ & $\begin{array}{l}71(13.4) \\
460(86.6)\end{array}$ & $\begin{array}{l}184(15.3) \\
1016(84.7)\end{array}$ & 0.13 \\
\hline \multicolumn{6}{|l|}{ Hypertension } \\
\hline $\begin{array}{l}\text { Yes } \\
\text { No }\end{array}$ & $\begin{array}{l}25(24.3) \\
78(75.7)\end{array}$ & $\begin{array}{l}131(23.1) \\
435(7.9)\end{array}$ & $\begin{array}{l}88(16.6) \\
443(83.4)\end{array}$ & $\begin{array}{l}244(20.3) \\
956(79.7)\end{array}$ & 0.01 \\
\hline \multicolumn{6}{|l|}{ Obesity /Overweight } \\
\hline $\begin{array}{l}\text { Yes } \\
\text { No }\end{array}$ & $\begin{array}{l}31(30) \\
72(70)\end{array}$ & $\begin{array}{l}147(26) \\
419(74)\end{array}$ & $\begin{array}{l}106(20) \\
425(80)\end{array}$ & $\begin{array}{l}284(23.7) \\
916(76.3)\end{array}$ & 0.14 \\
\hline \multicolumn{6}{|l|}{ High salt intake } \\
\hline $\begin{array}{l}\text { Yes } \\
\text { No }\end{array}$ & $\begin{array}{l}\text { 81(78.6) } \\
22(21.4)\end{array}$ & $\begin{array}{l}483(85.3) \\
83(14.7)\end{array}$ & $\begin{array}{l}\text { 436(82.1) } \\
\text { 95(17.9) }\end{array}$ & $\begin{array}{l}1000(83.3) \\
200(16.7)\end{array}$ & 0.14 \\
\hline \multicolumn{6}{|l|}{ High oil intake } \\
\hline $\begin{array}{l}\text { yes } \\
\text { no }\end{array}$ & 84(81.6) & $435(76.9)$ & $419(78.9)$ & 938(78.2) & \\
\hline \multicolumn{6}{|l|}{ Smoking } \\
\hline $\begin{array}{l}\text { Yes } \\
\text { No }\end{array}$ & $\begin{array}{l}6(5.8) \\
97(94.2)\end{array}$ & $\begin{array}{l}44(7.8) \\
522(92.2)\end{array}$ & $\begin{array}{l}38(7.2) \\
493(92.8)\end{array}$ & $\begin{array}{l}88(7.3) \\
1112(92.7)\end{array}$ & 0.76 \\
\hline \multicolumn{6}{|l|}{ Alcohol } \\
\hline $\begin{array}{l}\text { Yes } \\
\text { No }\end{array}$ & $\begin{array}{l}3(2.9) \\
100(97.1)\end{array}$ & $\begin{array}{l}12(2.1) \\
554(97.9)\end{array}$ & $\begin{array}{l}14(2.6) \\
517(97.4)\end{array}$ & $\begin{array}{l}29(2.4) \\
1171(97.6)\end{array}$ & 0.80 \\
\hline \multicolumn{6}{|l|}{ Renal Calculus } \\
\hline $\begin{array}{l}\text { Yes } \\
\text { No }\end{array}$ & $\begin{array}{l}1(1) \\
102(99)\end{array}$ & $\begin{array}{l}\text { 29(5.1) } \\
\text { 537(94.9) }\end{array}$ & $\begin{array}{l}32(6) \\
499(94)\end{array}$ & $\begin{array}{l}62(5.2) \\
1138(94.8)\end{array}$ & 0.10 \\
\hline \multicolumn{6}{|l|}{ UTI } \\
\hline Yes & $\mathbf{0}(\mathbf{0})$ & 30(5.3) & $24(4.5)$ & $54(4.5)$ & 0.05 \\
\hline No & 103(100) & $536(94.7)$ & $507(95.5)$ & $1146(95.5)$ & \\
\hline
\end{tabular}

\section{Protenuria and glycosuria with respect to socioeconomic status}

Out of the $12.3 \%$ individuals positive for urine albumin, maximum number of respondents belong to middle class $85(15 \%)$ compared to upper $12(11.7 \%)$ and lower class $51(9.6 \%)$. But glycosuria was not found to have statistically significant difference among the study population.(tab-3) 
Table3: Prevalence of Proteinuria and Glycosuria with respect to Socio-Economic Status

\begin{tabular}{|ccclll|}
\hline $\begin{array}{c}\text { NCD risk } \\
\text { factors }\end{array}$ & Upper & Middle & Lower & Total & $\begin{array}{c}\text { P } \\
\text { value }\end{array}$ \\
& $\mathrm{No}(\%)$ & $\mathrm{No}(\%)$ & $\mathrm{No}(\%)$ & $\mathrm{No}(\%)$ & \\
Urine & $\mathrm{N}=103$ & $\mathrm{~N}=566$ & $\mathrm{~N}=531$ & $\mathrm{~N}=1200$ & \\
$\begin{array}{c}\text { Albumin } \\
\text { Present }\end{array}$ & $12(11.7)$ & $85(15.0)$ & $51(9.6)$ & $148(12.3)$ & \\
Absent & $91(88.3)$ & $481(85.0)$ & $480(90.4)$ & $1052(87.7)$ & 0.004 \\
$\begin{array}{c}\text { Urine } \\
\text { Sugar }\end{array}$ & $8(7.8)$ & $46(8.1)$ & $46(8.7)$ & $100(8.3)$ & \\
$\begin{array}{c}\text { Present } \\
\text { Absent }\end{array}$ & $95(92.2)$ & $520(91.9)$ & $485(91.3)$ & $1100(91.7)$ & 0.86 \\
\hline
\end{tabular}

Fig-1 prevalence of DM with respect to Gender

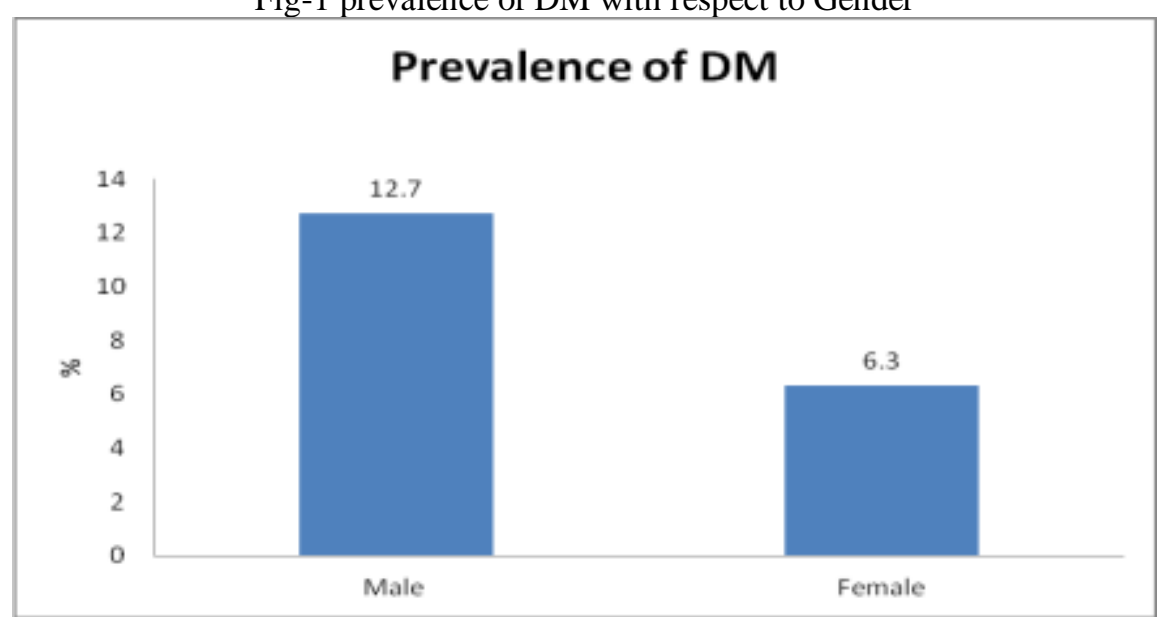

The prevalence of diabetes was more among males $(12.7 \%)$ than females $(6.3 \%)$.

IV. Discussion

Prevalence of risk factors for chronic kidney disease is increasing day by day due to the high prevalence of hypertension and diabetes in this region. Individuals with hypertension and diabetes are more prone for chronic kidney diseases compared to general population. However, progression to end stage renal disease can be halted with timely and regular medication and life style modification. The early biochemical markers for kidney disease are protenuria and glycosuria. These will give clue to the clinician to diagnose and confirm the kidney disease.

In our study with respect to CKD risk factors, we found that 184(15.3\%) individuals had DM, with majority (20.4\%) of them belonging to upper socioeconomic class. In the study by Venkatachalam et al in an area of rural Tamilnadu, out of the $8.6 \%$ diabetics, $10.6 \%$ respondents belonged to lower class compared to $6.4 \%$ and $3.9 \%$ in the upper and middle class respectively ${ }^{[10]}$.

In our study, the prevalence of DM was more common among males 49(12.7\%) compared to females57 (6.3\%). A similar study conducted in an urban area of Ahmedabad by Himanshu K et al also found higher prevalence among males $(16.9 \%){ }^{[11]}$. This could be due to higher prevalence of NCD risk factors among males.

The overall prevalence of hypertension was found to be $20.3 \%$. Gaurav R B et al in a community based study in urban area in India, found that the prevalence of hypertension was $23.9 \%{ }^{[12]}$. This study showed that the prevalence of hypertension is increasing in rural population as well.

The prevalence of proteinuria in our study population was $12.3 \%$, using albumin specific dipstick as a screening test with mean age of $50.28 \pm 15$ years.It was more prevalent in the age group more than or equal to 60 years $(19.8 \%)$. A Study conducted at Vellore showed that $11.7 \%$ of the individuals screened were found positive using dipstick test with a mean age of $50.94 \pm 11.2 \mathrm{yr}^{[13]}$. The findings of this study correlates with our study findings. Another study from Gujarat showed the prevalence of microalbuminuria to be $30 \%{ }^{(14)}$. This high variation could be because this study was hospital based were the prevalence of diseased individuals is more whereas our study was community based. 
The prevalence of glycosuria in the study population was $8.3 \%$ using dipstick as a screening test whereas in a study published in British Medical Journal stated that out of 5,562 people covered by the house-tohouse survey $148(2.7 \%)$ were found to have glycosuria ${ }^{[15]}$. This could be due to the fact that our study population had a higher prevalence of diabetes, hypertension and obesity.

\section{Contributions:}

Venkatachalam J: Conception and design of the study; planning and conducting the study; analysis and interpretation of data; and drafting the paper. Murugan N: Design of the study; providing guidance; and revising the draft critically for substantial intellectual content. Abraham SB: Design of the study; and revising the draft critically for substantial intellectual content. Zile Singh: Design of the study; planning and coordinating the study; Anil Purty: - Analysis and interpretation of data; drafting the paper and revising the draft critically for substantial intellectual content. Sathya GR: - Revising the draft critically for substantial intellectual content.

Conflict of Interest: - None.

Role of Funding Source: - Pondicherry Institute of Medical Sciences

\section{Acknowledgements:}

The authors would like to thank, Chairman PIMS Management committee, Director -Principal PIMS, for providing financial and transport support for this study. The authors want to extend thanks to final year part-I MBBS students for helping in data collection and data entry. Also extend thanks to Dr. Elangovan Veerappan, Nephrologist, who provided timely suggestions during the design and conduct of the study.

\section{References:}

[1] Park K. Concepts of health and disease. Park's Textbook of Preventive and Social Medicine $21^{\text {st }}$ edition; Banarsidas Bhanot Jabalpur 2011:11-43.

[2] Levey AS et al: National Kidney Foundation practice guidelines for chronic kidney disease: evaluation, classification, and stratification. Ann Intern Med 2003, 139:137-147.

[3] Haroun MK et al: Risk factors for chronic kidney disease: a prospective study of 23,534 men and women in Washington County, Maryland. J Am SocNephrol 2003, 14:2934-2941.

[4] Perneger TV, Brancati FL, Whelton PK, Klag MJ: End-stage renal disease attributable to diabetes mellitus. Ann Intern Med 1994, 121:912-918.

[5] Mohan V, Deepa M, Farooq S, Datta M, Deepa R: Prevalence, awareness and control of hypertension in Chennai - The Chennai Urban Rural Epidemiology Study (CURES-52). J Assoc Physicians India 2007, 55:326-332.

[6] Sarnak MJ et al: Kidney disease as a risk factor for development of cardiovascular disease: a statement from the American Heart Association Councils on Kidney in Cardiovascular Disease, High Blood Pressure Research, Clinical Cardiology, and Epidemiology and Prevention. Circulation 2003, 108:2154-2169.

[7] Ruggenenti P, Schieppati A, Remuzzi G: Progression, remission, regression of chronic renal diseases. Lancet 2001, 357:1601-1608.

[8] National Kidney Foundation: K/DOQI clinical practice guidelinesfor chronic kidney disease: evaluation, classification, and stratification. Am J Kidney Dis 2002, 39:S1-266.

[9] WHO: Overweight \& Obesity [http://www.who.int/mediacentre/factsheets/fs311/en/]

[10] Venkatachalam, J, Anil J. Purty, Zile Singh, Abraham SB, Narayanan S, Sathya GR, Natesan Bhumika, Joy Bazroy. Prevalence of Non Communicable Diseases (NCDs) in a Rural Population of South India. Indian Journal of Public Health Research \& Development (accepted on 24/2/2012.

[11] Nayak HK et al. Prevalence of type 2 diabetes in urban population of Ahmedabad, Gujarat. Indian Journal of Medical Specialities 2011; 2(2):101-105.

[12] Gaurav RB, Samel DR, kartikeyan S. Community based study on hypertension in an urban area. Antiseptic, 2002; 99 (6): 216-219.

[13] Isthiaque Ahmed, George T. John, Meshach G. Kirubakaran, Chakko K. Jacob \& Jayaprakash Muliyil Prevalence of proteinuria in rural adult population in Tamil Nadu.Indian J Med Res,2006:185-188.

[14] Deepak Parchwani, S.P. Singh. Microalbuminuria in diabetic patients: prevalence and putative risk factors. National Journal of Community Medicine, 2011;2 (1):126-129.

[15] John Harkness. Prevalence Of Glycosuria And Diabetes Mellitus: A Comprehensive Survey In An Urban Community. BMJ, 1962:1503-1507. 